Hans Grimmer* and Bernard Delley

\title{
Comparison of experimental and theoretical results for the structure and elastic properties of moganite
}

\section{DOI 10.1515/zkri-2016-1997}

Received August 22, 2016; accepted December 17, 2016; published online January 31, 2017

\begin{abstract}
Moganite, which is monoclinic at ambient temperature, undergoes a displacive transition to an orthorhombic phase at $\approx 570 \mathrm{~K}$. Whereas the monoclinic phase may be considered as $\alpha$-quartz that is Brazil twinned along $\left\{\begin{array}{llll}1 & 0 & \overline{1} & 1\end{array}\right\}$ at the unit-cell scale (cell-twinning), the orthorhombic phase cannot be interpreted as a Brazil celltwin of $\beta$-quartz, in contrast to statements made in the literature. The shape of the oxygen tetrahedra in monoclinic moganite has been determined more reliably by density functional theory (DFT) calculations than by experiment: the differences between the various experimental results for the shape of the oxygen tetrahedra at ambient temperature are typically ten times larger than the differences between the DFT results. The DFT calculations suggest that the oxygen tetrahedra in moganite are very close in shape to the oxygen tetrahedra in $\alpha$-quartz. Among the three DFT calculations considered, the most convincing results for the bond angles in moganite are obtained for the $\mathrm{DMol}^{3}$ code with functional PBE.
\end{abstract}

Keywords: Brazil twinning; density functional theory; elastic properties; moganite structure.

\section{Introduction}

Moganite, a mineral detected as microcrystalline silica fillings of cavities and cracks in ignimbrite flows near the town of Mogán in the south of Gran Canaria, was first described by Flörke, Jones and Schmincke [1] as $\mathrm{SiO}_{2}-G$. The name moganite was proposed by Flörke, Flörke and Giese [2]. After initial skepticism regarding the distinction between moganite and quartz, the "International

*Corresponding author: Hans Grimmer, Research with Neutrons and Muons, Paul Scherrer Institut, CH-5232 Villigen PSI, Switzerland, E-mail: hans.grimmer@psi.ch

Bernard Delley: Research with Neutrons and Muons, Paul Scherrer Institut, CH-5232 Villigen PSI, Switzerland
Commission on New Minerals and Mineral Names" approved moganite as a mineral species in 1999.

The structure of moganite was first determined by Miehe et al. [3]. It has space group $C 2 / c$ (\#15) and contains $12 \mathrm{Si}$ atoms and $24 \mathrm{O}$ atoms per conventional cell: $\mathrm{Si} 1$ at a position $4 e, \mathrm{Si2}, 01, \mathrm{O} 2$ and 03 at positions $8 f$. Later structure determinations were made by Miehe and Graetsch [4] and by Heaney and Post [5]. All these measurements were performed on powders of naturally occurring moganite, using X-ray diffraction and/ or time-of-flight neutron diffraction. They confirmed the room temperature result given above but led to considerable differences in the structure parameters. An obvious reason for the differences is that no pure moganite has been found in nature.

Moganite may be considered as a Brazil cell-twin of $\alpha$-quartz with composition plane $r=\left\{\begin{array}{llll}1 & 0 & \overline{1} & 1\end{array}\right\}$ and minimum lamellae thickness, i.e. thickness equal to the distance between neighboring ( $\left.\begin{array}{llll}1 & 0 & 1 & 1\end{array}\right)$ planes [3]. Let $\mathbf{a}_{q}, \mathbf{b}_{q}$ and $\mathbf{c}_{q}$ define the usual primitive hexagonal cell of quartz. Then $\mathbf{a}=\mathbf{a}_{q}-\mathbf{b}_{q}, \mathbf{b}=\mathbf{a}_{q}+\mathbf{b}_{q}, \mathbf{c}=2 \mathbf{c}_{q}$, is a body-centered orthogonal cell for the Brazil cell-twin, for which its space group \#15 appears in the setting $I 2 / a$. Note that the monoclinic angle $\beta$ is equal to $90^{\circ}$ for the unrelaxed cell-twin. To stress the structural relation between moganite and the quartz cell-twin, also the moganite structure is usually expressed in the setting $I 2 / a$, which has the advantage that the monoclinic angle $\beta$ is close to $90^{\circ}$. Grimmer and Delley $[6,7]$ considered cell-twin models. For a given choice of the data for the quartz structure and given orientation of the composition plane, the models have a continuous degree of freedom, which corresponds to a translation between left- and right-handed quartz parallel to the monoclinic axis of the cell-twin. In particular, the translation may be chosen such that either $\angle(\mathrm{O}-\mathrm{Si}-\mathrm{O})$ or $\angle(\mathrm{Si}-\mathrm{O}-\mathrm{Si})$ has the same value as in quartz also across the composition plane. In the first case (model 1 of [6]) the oxygen tetrahedra are undistorted compared to quartz, in the second (model 3 of [6]) the angles between adjacent oxygen tetrahedra are as in quartz. It turns out that model 1 is closer to the experimental results. 
Calculations of the moganite structure using density functional theory (DFT) were done by Hantsch et al. [8] and by us for the present paper. They correspond to moganite at a temperature of $0 \mathrm{~K}$ and will be compared to the experimental data at ambient temperature and to cell-twin model 1, based either on the quartz data of Lager et al. [9] at $13 \mathrm{~K}$ or on those of Baur [10] at $291 \mathrm{~K}$.

\section{Moganite, its structure determined by theory and experiment}

\section{Brazil cell-twin models}

Figure 1 illustrates the structure of moganite by showing the cell-twin model based on quartz data [10] at $291 \mathrm{~K}$ projected parallel to its monoclinic axis $\mathbf{b}$. 01 binds to two Si2, $\mathrm{O} 2$ (and O3) to a Si1 and a Si2. O3 connects two oxygen tetrahedra, the central Si atoms of which lie on opposite sides of a Brazil twin boundary (marked in brown). The bonds are indicated by arrows. The atom at the arrowhead has the larger $y$ coordinate. The figure shows the situation for model 1; the figure for model 3 is identical except that the arrows that cross a Brazil twin boundary have their head at the opposite end of the dark green line. The corresponding figure for the cell-twin based on the quartz data of Lager et al. [9] at $13 \mathrm{~K}$ looks practically the same; the corresponding figures for the experimental and DFT results mentioned in the introduction differ only slightly; for all of them the sense of the arrows is the same as for cell-twin model 3. This tells us that, as far as possible, relaxation conserves the angles $(\mathrm{O}-\mathrm{Si}-\mathrm{O})$ as well as (Si-O-Si) of quartz.

Columns M1,2 of Table 1 describe unrelaxed Brazil cell-twins, whose tetrahedra formed by $4 \mathrm{O}$ atoms bound to the same Si atom have the same bond distances and bond angles as the corresponding tetrahedra in $\alpha$-quartz. Only the $\mathrm{Si}-\mathrm{O}-\mathrm{Si}$ angles between two tetrahedra having $\mathrm{O}$ in common and the two $\mathrm{Si}$ on opposite sides of a twin boundary have values different from the values for $\alpha$-quartz. The model given in column M2 corresponds to model 1 in Table 2 of [6]; Grimmer and Delley [7] show how the value $Y=2 \delta=0.4395$ given for this model is related to the fault vector $\mathbf{f}$ of Lang [11] and the displacement vector $\mathbf{R}$ of Phakey [12], in particular $|\mathbf{f}|=0.4395 a$, where $a, c$ are the lattice parameters of quartz. Column M1 is based on low temperature data for quartz, which lead to a fault vector $|\mathbf{f}|=0.4464 a$.

Figure 2 gives a graphical representation of the results in the lower part of Table 1.

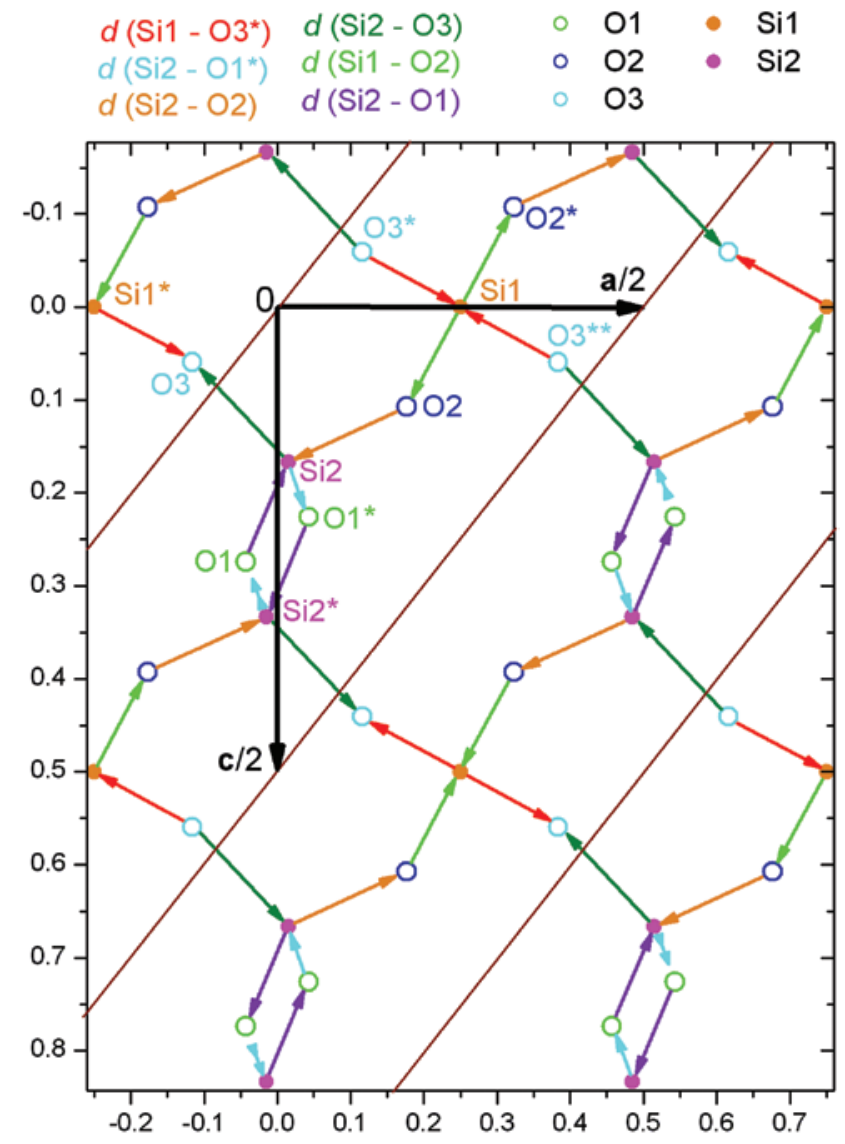

Fig. 1: A conventional /-centered monoclinic cell of moganite projected parallel to its monoclinic axis $\mathbf{b}$. The named atoms are those at positions $x \mathbf{a}+y \mathbf{b}+z \mathbf{c}$, whose coordinates $(x, y, z)$ are obtained from column M2 of Table 1 as follows: Si1(1/4,y1,0), Si1* $(-1 / 4$, $-y 1,0), \operatorname{Si} 2(x 2, y 2, z 2), \operatorname{Si}{ }^{\star}(-x 2, y 2+1 / 2,-z 2+1 / 2), 01(X 1, Y 1, Z 1)$, $01 *(-X 1, Y 1+1 / 2,-Z 1+1 / 2), 02(X 2, Y 2, Z 2), 02 *(-X 2+1 / 2, Y 2,-Z 2)$, $03(X 3, Y 3, Z 3), 03 *(-X 3,-Y 3,-Z 3), 03^{\star *}(X 3+1 / 2,-Y 3, Z 3)$. Si and 0 atoms connected by arrows of the same color have the same distance; this holds not only for M2 but for all eight cases considered in Table 1. The atom at the arrow-head has the larger $y$ coordinate; double arrows start at an 0 -atom in the unit cell below or end at an 0 -atom in the unit cell above. The brown lines show the twin boundaries of the Brazil cell-twin models considered in Table 1. The sense of the dark green arrows holds for both cell-twin models, M1 and $\mathrm{M} 2$; it is opposite for all the experimental and DFT results given in the last six columns of Table 1.

\section{Experimental results}

The structure of moganite has been determined experimentally in [3-5]. So far, it has not been possible to synthesize moganite as a pure phase; in nature it is found intergrown with fine-grained quartz and containing small amounts of volatile $\left(\mathrm{H}_{2} \mathrm{O}, \mathrm{CO}_{2}\right)$ and non-volatile $\left(\mathrm{Na}_{2} \mathrm{O}\right.$, $\mathrm{K}_{2} \mathrm{O}, \mathrm{Fe}_{2} \mathrm{O}_{3}, \ldots$ ) impurities. Relatively pure moganite from Gran Canaria was used in [3-5]. Typical impurities are 
Tab. 1: Cell parameters $a, b, c, \beta$ and position parameters of moganite in $/ 12 / a 1$ setting; cell volume $V$, bond distances $d$ and bond angles according to various authors. In columns M1,2 the Brazil cell-twin model 1 of Grimmer and Delley [6, 7] with minimum lamellae thickness $(\mathrm{N}=1)$ is interpreted as moganite. Column $\mathrm{E} 2$ uses for $\mathrm{O} 2$ the position parameters adjusted by distance least squares, not the ones obtained by unconstrained structure refinement.

\begin{tabular}{|c|c|c|c|c|c|c|c|c|c|}
\hline & & \multicolumn{2}{|c|}{ Brazil twin models } & \multicolumn{3}{|c|}{ Experimental results } & \multicolumn{3}{|r|}{ DFT result } \\
\hline & & $\begin{array}{r}\text { M1 using } \\
13 \mathrm{~K} \text { data [9] }\end{array}$ & $\begin{array}{r}\text { M2 using } \\
291 \mathrm{~K} \text { data [10] }\end{array}$ & $\begin{array}{r}\text { E1 Miehe } \\
\text { et al. [3] }\end{array}$ & $\begin{array}{r}\text { E2 Miehe and } \\
\text { Graetsch [4] }\end{array}$ & $\begin{array}{r}\text { E3 Heaney } \\
\text { and Post [5] }\end{array}$ & $\begin{array}{r}\text { D1 Hantsch } \\
\text { et al. [8] }\end{array}$ & $\begin{array}{r}\text { D2 } \text { DMol }^{3} \\
\text { PBE }\end{array}$ & $\begin{array}{r}\text { D3 } \text { DMol }^{3} \\
\text { PBEsol }\end{array}$ \\
\hline & $a[\AA ̊]$ & $4.9021 \cdot \sqrt{ } 3$ & $4.913 \cdot \sqrt{3}$ & $8.770(2)$ & $8.758(2)$ & $8.7371(6)$ & 8.903 & 8.792 & 8.611 \\
\hline & $b[\AA ̊]$ & 4.9021 & 4.913 & 4.879(1) & $4.876(1)$ & $4.8692(3)$ & 4.995 & 4.976 & 4.861 \\
\hline & $c[\AA]$ & 10.7994 & 10.809 & $10.720(2)$ & $10.715(2)$ & $10.7217(7)$ & 10.907 & 10.877 & 10.735 \\
\hline & $\beta\left[^{\circ}\right]$ & 90 & 90 & $90.08(4)$ & $90.08(3)$ & 90.193(9) & 90.36 & 90.64 & 90.52 \\
\hline & $V\left[\AA^{3}\right]$ & 449.48 & 451.9 & 458.7(3) & $457.6(3)$ & $456.12(5)$ & 485.0 & 475.8 & 449.3 \\
\hline \multicolumn{10}{|c|}{ Si1 in 4(e) } \\
\hline & $x 1$ & $1 / 4$ & $1 / 4$ & $1 / 4$ & $1 / 4$ & $1 / 4$ & $1 / 4$ & $1 / 4$ & $1 / 4$ \\
\hline & $y 1$ & -0.0588 & -0.06035 & $-0.0228(20)$ & $-0.0092(17)$ & $-0.0274(11)$ & -0.0177 & -0.0315 & -0.0382 \\
\hline & $z 1$ & 0 & 0 & 0 & 0 & 0 & 0 & 0 & 0 \\
\hline \multicolumn{10}{|c|}{ Si2 in $8(f)$} \\
\hline & $x 2$ & 0.0160 & 0.01505 & $0.0072(5)$ & $0.0115(4)$ & $0.0103(3)$ & 0.0077 & 0.0144 & 0.0174 \\
\hline & $y^{2}$ & 0.2392 & 0.23480 & $0.2507(7)$ & $0.2533(6)$ & $0.2486(7)$ & 0.2363 & 0.2399 & 0.2527 \\
\hline & $z 2$ & $1 / 6$ & $1 / 6$ & $0.1688(4)$ & $0.1678(2)$ & $0.1682(4)$ & 0.1668 & 0.1669 & 0.1666 \\
\hline \multicolumn{10}{|c|}{01 in $8(f)$} \\
\hline & $X 1$ & -0.0438 & -0.04305 & $-0.0196(9)$ & $-0.0314(12)$ & $-0.0219(3)$ & -0.0142 & -0.0268 & -0.0326 \\
\hline & $Y 1$ & 0.0382 & 0.03010 & $0.0701(13)$ & $0.0680(13)$ & $0.0644(5)$ & 0.0406 & 0.0505 & 0.0712 \\
\hline & $Z 1$ & 0.275183 & 0.273933 & $0.2923(7)$ & $0.2860(5)$ & $0.2878(2)$ & 0.2840 & 0.2852 & 0.2879 \\
\hline \multicolumn{10}{|c|}{02 in $8(f)$} \\
\hline & $X 2$ & 0.1794 & 0.17670 & $0.1667(7)$ & 0.1711 & $0.1678(3)$ & 0.1627 & 0.1785 & 0.1847 \\
\hline & $Y 2$ & 0.1314 & 0.12915 & $0.1671(12)$ & 0.1770 & $0.1708(5)$ & 0.1703 & 0.1582 & 0.1554 \\
\hline & $Z 2$ & 0.108517 & 0.107267 & $0.1030(6)$ & 0.1050 & $0.1002(3)$ & 0.0969 & 0.1081 & 0.1123 \\
\hline \multicolumn{10}{|c|}{03 in $8(f)$} \\
\hline & $x 3$ & -0.1144 & -0.11635 & $-0.1274(6)$ & $-0.1343(5)$ & $-0.1297(3)$ & -0.1321 & -0.1184 & -0.1131 \\
\hline & $Y 3$ & $1 / 4$ & $1 / 4$ & $0.2217(19)$ & $0.2148(12)$ & $0.2296(5)$ & 0.2062 & 0.2236 & 0.2342 \\
\hline & $Z 3$ & 0.05815 & 0.05940 & $0.0668(6)$ & $0.0739(8)$ & $0.0675(3)$ & 0.0727 & 0.0605 & 0.0561 \\
\hline 1 & $d(\mathrm{Si} 1-02)[\AA ̊]$ & 1.6131 & 1.6125 & 1.6166 & 1.6030 & 1.6145 & 1.6168 & 1.6383 & 1.6331 \\
\hline 2 & $d\left(\mathrm{Si} 1-03^{*}\right)[\AA]$ & 1.6120 & 1.6043 & 1.6151 & 1.6299 & 1.6102 & 1.6144 & 1.6336 & 1.6266 \\
\hline 3 & $d\left(\mathrm{Si} 2-01^{\star}\right)[\AA ̊]$ & 1.6120 & 1.6043 & 1.6168 & 1.6217 & 1.6115 & 1.6128 & 1.6343 & 1.6282 \\
\hline 4 & $d(\mathrm{Si} 2-02)[\AA ̊]$ & 1.6120 & 1.6043 & 1.6197 & 1.5961 & 1.6048 & 1.6147 & 1.6358 & 1.6293 \\
\hline 5 & $d(\mathrm{Si} 2-01)[\AA]$ & 1.6131 & 1.6125 & 1.6079 & 1.6009 & 1.5907 & 1.6214 & 1.6390 & 1.6339 \\
\hline 6 & $d(\mathrm{Si} 2-03)[\AA]$ & 1.6131 & 1.6125 & 1.6141 & 1.6354 & 1.6314 & 1.6155 & 1.6365 & 1.6296 \\
\hline 7 & $\begin{array}{l}\angle\left(02-\mathrm{Si} 1-03^{*}\right) \\
\angle\left(02^{\star}-\mathrm{Si} 1-03^{\star *}\right)\left[{ }^{\circ}\right]\end{array}$ & 110.7 & 110.4 & 110.2 & 114.9 & 111.9 & 110.3 & 110.5 & 110.9 \\
\hline 8 & $\angle\left(02^{*}-\mathrm{Si} 1-02\right)\left[^{\circ}\right]$ & 109.4 & 109.5 & 110.1 & 111.0 & 106.6 & 109.0 & 109.6 & 109.6 \\
\hline 9 & $\begin{array}{l}\angle\left(02-\mathrm{Si} 1-03^{\star *}\right), \\
\angle\left(02^{*}-\mathrm{Si} 1-03^{*}\right)\left[^{\circ}\right]\end{array}$ & 108.6 & 108.8 & 110.0 & 106.0 & 111.0 & 109.3 & 108.9 & 108.5 \\
\hline 10 & $\angle\left(03^{*}-\mathrm{Si} 1-03^{* *}\right)\left[^{\circ}\right]$ & 108.9 & 109.0 & 106.1 & 104.1 & 104.6 & 108.6 & 108.4 & 108.3 \\
\hline 11 & $\angle\left(01^{*}-\mathrm{Si} 2-01\right)\left[^{\circ}\right]$ & 108.6 & 108.8 & 109.0 & 108.5 & 108.2 & 108.1 & 107.9 & 107.2 \\
\hline 12 & $\angle\left(01^{*}-\mathrm{Si} 2-02\right)\left[^{\circ}\right]$ & 108.9 & 109.0 & 107.3 & 104.8 & 107.8 & 108.7 & 107.7 & 108.3 \\
\hline 13 & $\angle(01-\mathrm{Si} 2-02)\left[^{\circ}\right]$ & 110.7 & 110.4 & 110.4 & 114.1 & 112.8 & 110.9 & 111.6 & 111.7 \\
\hline 14 & $\angle(01-\mathrm{Si} 2-03)\left[^{\circ}\right]$ & 109.4 & 109.5 & 113.7 & 103.8 & 111.5 & 110.4 & 111.4 & 111.4 \\
\hline 15 & $\angle(02-\mathrm{Si} 2-03)\left[^{\circ}\right]$ & 108.6 & 108.8 & 108.3 & 113.4 & 109.2 & 109.8 & 109.7 & 109.2 \\
\hline 16 & $\angle\left(01^{*}-\mathrm{Si} 2-03\right)\left[{ }^{\circ}\right]$ & 108.9 & 110.4 & 107.9 & 112.3 & 107.1 & 109.0 & 108.5 & 108.9 \\
\hline 17 & $\angle\left(\mathrm{Si} 2-01-\mathrm{Si}^{\star}\right)\left[^{\circ}\right]$ & 142.4 & 143.7 & 136.9 & 138.6 & 139.7 & 145.7 & 141.2 & 137.0 \\
\hline 18 & $\angle(\mathrm{Si} 1-02-\mathrm{Si} 2)\left[^{\circ}\right]$ & 142.4 & 143.7 & 146.4 & 143.8 & 145.8 & 147.5 & 140.4 & 138.0 \\
\hline 19 & $\angle\left(\mathrm{Si}^{*}-03-\mathrm{Si} 2\right)\left[^{\circ}\right]$ & 139.0 & 138.8 & 147.0 & 148.6 & 145.0 & 149.6 & 144.2 & 142.6 \\
\hline
\end{tabular}

1-3 \% $\mathrm{H}_{2} \mathrm{O}, 0.2-1 \% \mathrm{CO}_{2}$, and less than $0.2 \%$ non-volatile impurities by weight [4]. Powder diffraction and Rietveld refinement were used in [3-5] for structure determination.
Miehe et al. [3] used time-of-flight (TOF) neutron scattering and X-ray diffraction, Miehe and Graetsch [4] used $\mathrm{Cu} \mathrm{K} \alpha$ X-ray diffraction, Heaney and Post [5] used TOF 

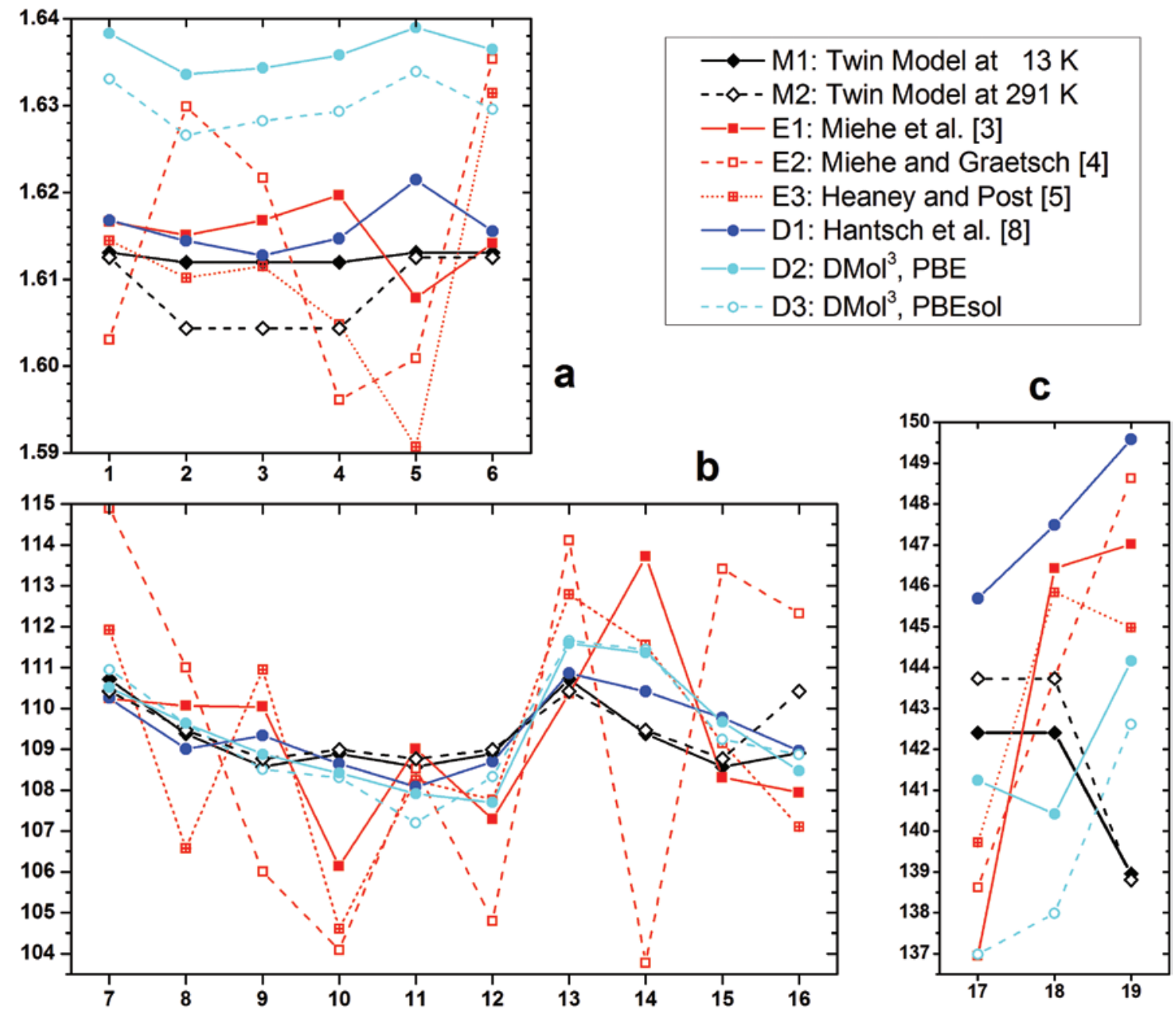

Fig. 2: (a) Shows Si-O distances in $\AA$, (b) O-Si-O angles and (c) Si-O-Si angles in ${ }^{\circ}$. The lines are a guide to the eye. The numbers $1-19$ refer to the corresponding rows of Table 1. Experimental values are shown in red, DFT results in blue or cyan. The values in black correspond to Brazil cell-twin model 1 with minimum lamellae thickness of Grimmer and Delley [6,7] based on quartz data at $13 \mathrm{~K}[9]$ and at $291 \mathrm{~K}[10]$, respectively. Distance 6 as well as angles 14-16 and 19 correspond to atoms on different sides of Brazil twin boundaries. Distances 1-2 and angles 7-10 involve Si1, distances 3-6 and angles 11-16 involve Si2.

neutron scattering at $298 \mathrm{~K}$. Their results are given in columns E1-E3 of Table 1.

Cell parameters and cell volume of moganite can be determined more reliably by experiment than by Brazil twin models or DFT calculations. Nevertheless, the differences between the values given in columns E1-E3 of Table 1 are in most cases much larger than the experimental uncertainties given by the authors, as shown in Figure 3. According to [5], the actual errors may be more than an order of magnitude higher than the deviations shown, which were obtained by the General Structure Analysis System (GSAS) [13].

Let us denote the values in the various columns of Table 1 by the corresponding subscript. Cell parameters and cell volume can be determined reliably by experiment. Neglecting deviations from the nominal $\mathrm{Si}_{12} \mathrm{O}_{24}$ cell content, the density $\rho$ will be inversely proportional to the cell volume $V$. The density of $\alpha$-quartz at room temperature corresponds to the cell volume $V_{\mathrm{M} 2}$. The experimentally determined cell volumes of moganite, $V_{\mathrm{E} 1}, V_{\mathrm{E} 2}$ and $V_{\mathrm{E} 3}$ being larger than $V_{\mathrm{M} 2}$, moganite will have slightly smaller density than quartz.

Also for the position parameters, the differences between the values given in columns E1-E3 of Table 1 are in most cases much larger than the experimental uncertainties given by the authors, as shown in Figure 4.

Whereas unconstrained structure refinement led to plausible $\mathrm{Si}-\mathrm{O}$ distances for the neutron data [5], it produced for the $\mathrm{Cu} \mathrm{K} \alpha$ data [4] an $\mathrm{O} 2$ position unrealistically far from Si1 (1.643 $\AA$ ) and unrealistically close to Si2 (1.537 ̊̊). The E2 position parameters for $\mathrm{O} 2$ were therefore adjusted by minimizing the sum of the squared 


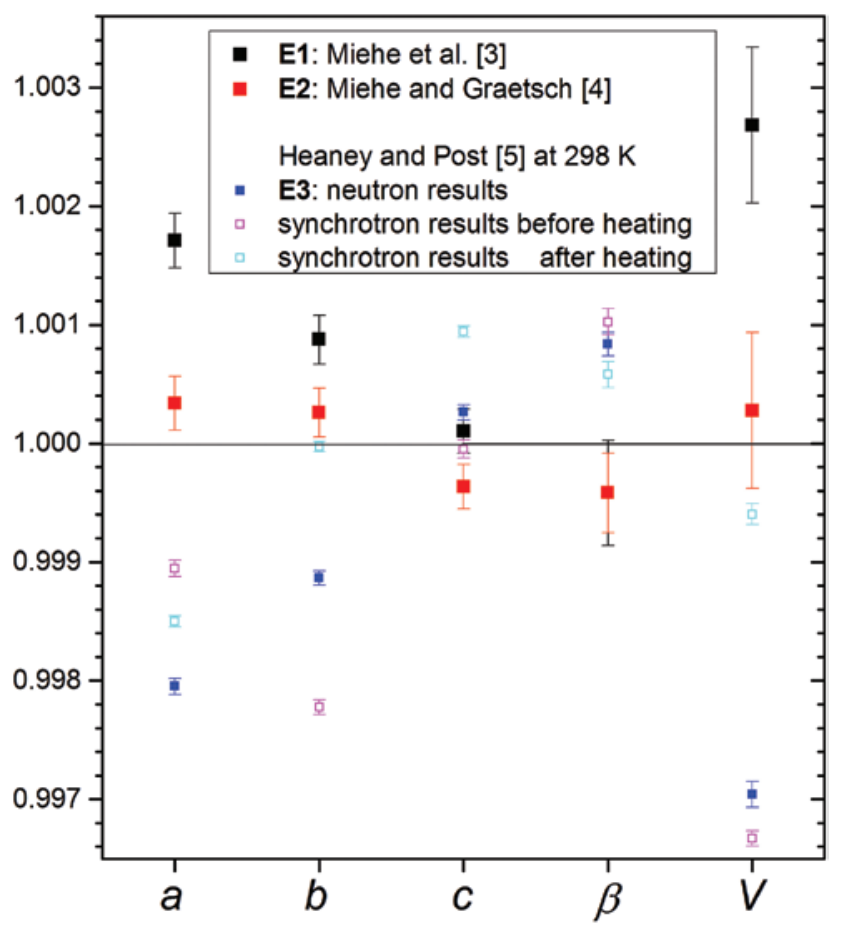

Fig. 3: Experimental values of the cell parameters and cell volume of moganite given in columns E1, E2 and E3 of Table 1 divided by their average. Synchrotron powder X-ray diffraction results at $298 \mathrm{~K}$ before and after heating to $1354 \mathrm{~K}$ are also given [5]. These values were not considered for computing the average.

$\mathrm{Si}-\mathrm{O} 2$ distances. The results of Heaney and Post [5] can be expected to be the most reliable experimental results because structure refinement based on their powder neutron diffraction data was possible without restraints.

Figures $2 \mathrm{a}$ and $\mathrm{b}$ show that the shapes of the O-tetrahedra are difficult to determine experimentally. The results of [3] and [4] differ widely: whereas according to [3] $d(\mathrm{Si} 2-02)(\# 4)$ is the largest among the $\mathrm{Si}-\mathrm{O}$ distances and $\angle(\mathrm{O} 1-\mathrm{Si2}-03)(\# 14)$ the largest among the $\mathrm{O}-\mathrm{Si}-\mathrm{O}$ angles, they are the smallest distance and smallest angle according to [4], the results of [5] lying in between. These discrepancies suggest that the true $\mathrm{Si}-\mathrm{O}$ distances \#1-5, the true $\mathrm{O}-\mathrm{Si}-\mathrm{O}$ angles $\# 7-13$ and the true $\mathrm{Si}-\mathrm{O}-\mathrm{Si}$ angles \#17-18 will be closer to the cell-twin model values than to the experimental ones. Relaxation of the atom positions in the models will mainly affect the remaining distances and angles, which involve atoms on both sides of a Brazil twin boundary.

\section{Density functional theory calculations}

Columns D2 and D3 of Table 1 give the results of density functional theory (DFT) calculations with the $\mathrm{DMol}^{3}$ code

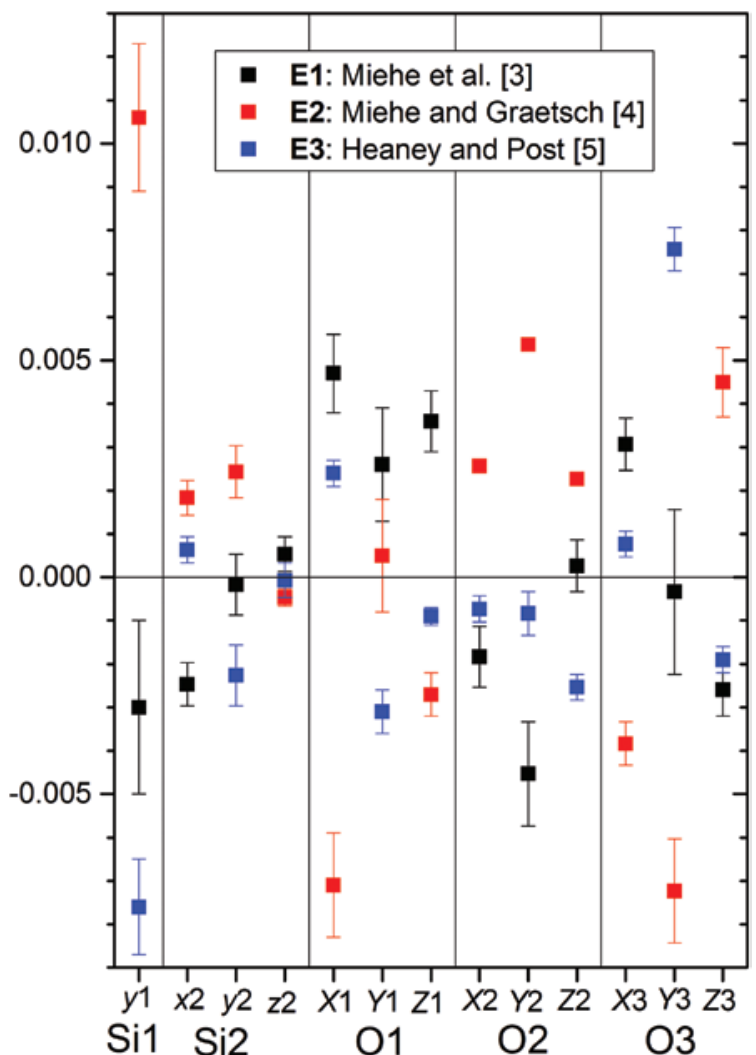

Fig. 4: Difference between the experimental values of the position parameters given in columns E1, E2 and E3 of Table 1 and the average of these 3 values. (Note that no uncertainties are given for $\mathrm{O} 2$ in $\mathrm{E} 2$ ).

[14, 15], using the functional $\mathrm{PBE}$ as defined in [16] for D2 and the functional PBEsol as defined in [17] for D3. Whereas PBEsol tends to underestimate the cell volume ( $V_{\mathrm{D} 3}$ is $1.8 \%$ smaller than $V_{\mathrm{E} 2}$ ), PBE tends to overestimate it $\left(V_{\mathrm{D} 2}\right.$ is $4.0 \%$ larger than $\left.V_{\mathrm{E} 2}\right)$. In both cases a $4 \times 4 \times 4$ $\Gamma$-centered mesh in $\mathbf{k}$-space was used as well as the default local orbital basis set DNP [15] with cutoff radii for the basic functions equal to $7.32 a_{0}$ for $\mathrm{O}$ and $10.06 a_{0}$ for $\mathrm{Si}, a_{0}$ denoting the Bohr radius. The calculations minimized energy with respect to the parameters defining the moganite cell and the Wyckoff positions, starting out with the moganite structure given in [4]. The results of Hantsch et al. [8] are given for comparison in column D1. Also they used the functional PBE.

As discussed in Section Experimental results, we can assume that the true $\mathrm{Si}-\mathrm{O}$ distances in moganite at room temperature are close to the experimental values for $\alpha$-quartz, which appear in the Brazil cell-twin model M2 of moganite. Although the parameters for the moganite cell obtained in D1 are on average 2\% larger than the experimental values, the $\mathrm{Si}-\mathrm{O}$ distances are only $0.5 \%$ larger than the $\mathrm{Si}-\mathrm{O}$ distances in quartz. This means that 
the distances between neighboring oxygen tetrahedra and, therefore, the $\mathrm{Si}-\mathrm{O}-\mathrm{Si}$ angles must be larger than in reality. The opposite situation occurs for D3, where the parameters for the moganite cell are on average $0.6 \%$ too small and the $\mathrm{Si}-\mathrm{O}$ distances $1.4 \%$ larger than for quartz. This means that the $\mathrm{Si}-\mathrm{O}-\mathrm{Si}$ angles must be smaller than in reality. For D2 the parameters for the moganite cell are on average $1.3 \%$ too large and the $\mathrm{Si}-\mathrm{O}$ distances $1.7 \%$ larger than for quartz, so that the $\mathrm{Si}-\mathrm{O}-\mathrm{Si}$ angles will be only little smaller than in reality. This situation is clearly shown in Figure 2c. Table 1 shows that all the 13 independent Wyckoff parameters D2 lie between the corresponding values D1 and D3, the only exception being $z 2$, for which all three values are almost equal.

Also the other suggestion made in Section Experimental results that the $\mathrm{O}-\mathrm{Si}-\mathrm{O}$ and $\mathrm{Si}-\mathrm{O}-\mathrm{Si}$ angles obtained in the Brazil cell-twin models are close to reality for the cases where the atoms involved are not separated by a Brazil twin boundary is substantiated by the DFT results: The DFT results D1-D3 for the O-Si-O angles \#7-13 and the $\mathrm{D} 2$ results for the $\mathrm{Si}-\mathrm{O}-\mathrm{Si}$ angles \#17-18 are close to the cell-twin model results. For the $\mathrm{O}-\mathrm{Si}-\mathrm{O}$ angle \#14 and, in particular, the $\mathrm{Si}-\mathrm{O}-\mathrm{Si}$ angle \#19 the DFT results D1-D3 deviate more strongly from the results M1-M2. Figure $2 \mathrm{~b}$ clearly shows that the results of the three DFT calculations give more consistent results than the experiments E1-E3. We conclude that the DFT results, and in particular D2 give a better description of the Wyckoff position parameters and $\mathrm{O}-\mathrm{Si}-\mathrm{O}$ and $\mathrm{Si}-\mathrm{O}-\mathrm{Si}$ angles of moganite than the experimental results E1-E3.

As for the experimental results shown in Figure 3, the differences of the various DFT results are largest for lattice parameter $a$. The situation is similar for the position parameters of Si: the DFT results differ most for the $y$ parameter of $\mathrm{Si} 1$ and least for the $z$ parameter of $\mathrm{Si2}$, as is the case for the experimental results shown in Figure 4.

Comparing the position parameters of Si1, Si2, O1, 02 and 03 in column D3 of Table 1 with the corresponding parameters in either column M1 or M2 we see that our DFT results differ from the two Brazil cell-twin models mainly in the $y$-coordinate, i.e. perpendicular to the plane shown in Figure 1. The difference in the $y$-coordinate has opposite sign for $\mathrm{O} 3$ than for Si1, Si2, $\mathrm{O} 1$ and 02. The largest shift in each of $x, y$ and $z$ has 01 .

Denote by $\Delta E$ the bond enthalpy per mole $\mathrm{SiO}_{2}$ of moganite compared to $\alpha$-quartz. Hantsch et al. [8] obtained $\Delta E_{\mathrm{D} 1}=-0.35 \mathrm{~kJ} / \mathrm{mol}$, i.e. moganite should be the stable phase according to the sign of $\Delta E_{\mathrm{D} 1}$. However, its absolute value is less than the uncertainty of their calculations, which they estimate at $4 \mathrm{~kJ} / \mathrm{mol}$. Taking lattice and position parameter relaxation into account, we obtained $\Delta E_{\mathrm{D} 2}=0.4 \mathrm{~kJ} / \mathrm{mol}$ and $\Delta E_{\mathrm{D} 3}=0.7 \mathrm{~kJ} / \mathrm{mol}$, stating that $\alpha$-quartz is the stable phase at low temperature and pressure. These values are smaller than the experimental CODATA value at $25^{\circ} \mathrm{C}$ and atmospheric pressure $\Delta E=3.4 \pm 0.7 \mathrm{~kJ} / \mathrm{mol}[18]$.

\section{$\alpha$ - and $\beta$-moganite}

Heaney and Post [5] also investigated the dependence of the lattice parameters on temperature between 100 and $1354 \mathrm{~K}$ using synchrotron X-ray diffraction. They found a reversible displacive phase transition from monoclinic $\alpha$-moganite to orthorhombic $\beta$-moganite at $569 \mathrm{~K}$. Whereas in [5] it is argued that the transition from $\alpha$ - to $\beta$-moganite is second-order, hard-mode Raman spectroscopy results indicate that the situation is more involved [19].

Similarly as in [4], constraints were used also in [5] for structure refinement from their X-ray data: all $\mathrm{Si}-\mathrm{O}$ bonds were assumed to be of length $1.61 \AA$ An $\beta$-moganite. Table 2 shows that the structure given in Tables 4 and 5 of [5] for $\beta$-moganite at $1354 \mathrm{~K}$ is close to the structure proposed in [20] for moganite at room temperature before it was recognized that moganite has only monoclinic symmetry at ambient conditions [3]. Following Heaney and Post [5] we use the setting Imab of space group Ibam (\#72) to facilitate comparison with monoclinic moganite. The atom position parameters given in [5] for $\alpha$-moganite at $298 \mathrm{~K}$ and for $\beta$-moganite at $1354 \mathrm{~K}$ differ at most by 0.03 .

Figure 5 illustrates the structure of $\alpha$-moganite as obtained by the $\mathrm{DMol}^{3}$ code with functional PBE and $\beta$-moganite as determined in [5].

It is interesting to compare the transition in moganite with the transition from $\alpha$ - to $\beta$-quartz, which takes place

Tab. 2: The structure of orthorhombic moganite (with space group Ibam) in Imab setting.

\begin{tabular}{lrr}
\hline $\begin{array}{l}\text { Cell and } \\
\text { position } \\
\text { parameters }\end{array}$ & $\begin{array}{r}\text { Heaney and Post [5] } \\
\text { for moganite at } \\
1354 \mathrm{~K}\end{array}$ & $\begin{array}{r}\text { Miehe et. al. [20] for } \\
\text { moganite at room } \\
\text { temperature }\end{array}$ \\
\hline$a[\AA]$ & $8.8159(9)$ & 8.74 \\
$b[\AA]$ & $4.9371(5)$ & 4.88 \\
$c[\AA]$ & $10.7605(14)$ & 10.70 \\
Si 1 in $4 a$ & $1 / 4,0,0$ & $1 / 4,0,0$ \\
Si2 in $8 j$ & $0,0.2255(6), 0.1701(3)$ & $0,0.250,0.170$ \\
01 in $8 j$ & $0,0.0416(7), 0.2935(4)$ & $0,0.065,0.290$ \\
02 in $16 k$ & $0.1471(3), 0.2007(6)$, & $0.147,0.189,0.086$ \\
& $0.0824(5)$ & $1.57-1.60$ \\
$d(\mathrm{Si}-0)[\AA]$ & 1.61 & $105.4-110.7$ \\
$\angle(0-\mathrm{Si}-0)\left[{ }^{\circ}\right]$ & $102.5-116.2$ & $140.7,153.3$ \\
$\angle(\mathrm{Si}-0-\mathrm{Si})\left[^{\circ}\right]$ & $138.5,145.5$ & \\
\hline
\end{tabular}



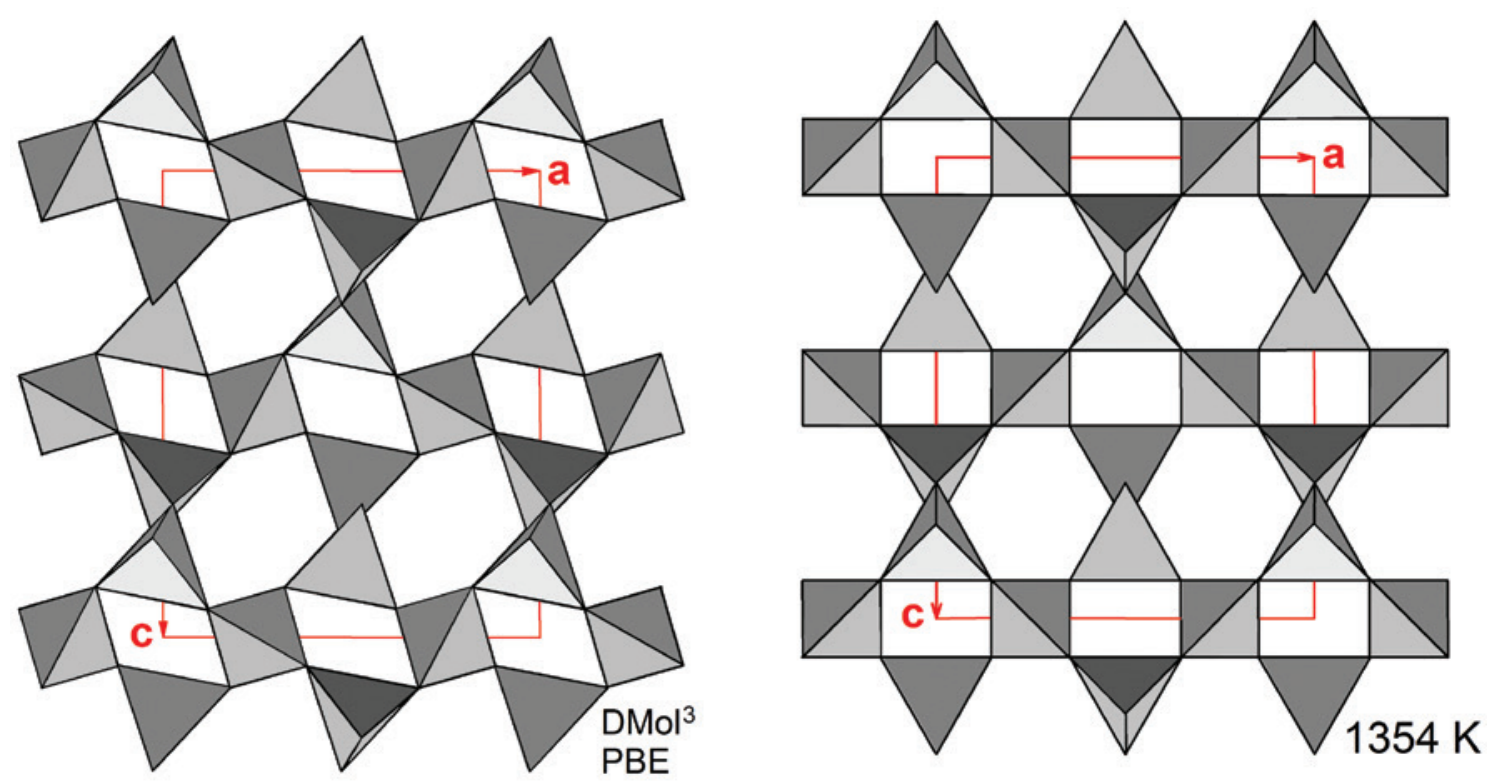

Fig. 5: Oxygen tetrahedra of $\alpha$-moganite (left) with space group \#15 in $/ 2 / a$ setting and $\beta$-moganite (right) with space group \#72 in Imab setting.

at $847 \mathrm{~K}$ and is of first order [21]. Whereas the structure of $\alpha$-moganite can be interpreted as Brazil cell-twinned $\alpha$-quartz, $\beta$-moganite cannot be interpreted as Brazil cell-twinned $\beta$-quartz although the contrary is stated in [20] and suggested in Table 5 of [4]. In fact, a periodically Brazil twinned $\alpha$ - or $\beta$-quartz cannot have space group Ibam; stacking ( $10 \overline{1} 1)$ layers alternately of left- and righthanded quartz mentioned in [20] produces monoclinic, not orthorhombic moganite.

Using molecular dynamics simulations Murashov and Svishchev [22] found that at ambient temperature and pressure $\beta$-moganite has the lowest enthalpy among pure silica phases, $5.5 \mathrm{~kJ} / \mathrm{mol}$ lower than $\alpha$-quartz. This is in contradiction with experiment and DFT results. (Note that it was for $\alpha$-moganite that a slightly lower enthalpy $(0.35 \mathrm{~kJ} / \mathrm{mol})$ than for $\alpha$-quartz was obtained in [8].) Also the distribution of $\mathrm{Si}-\mathrm{O}-\mathrm{Si}$ angles in $\beta$-moganite given in Figure 3 of [22] shows unrealistic maxima at $130^{\circ}$ and $159^{\circ}$, which contrast with the values $138.5^{\circ}$ and $145.5^{\circ}$ obtained in [5]. No phase transition of moganite at ambient pressure was found in [22] for the temperature range from $100 \mathrm{~K}$ to $1100 \mathrm{~K}$ in contrast to experiment [5].

\section{Elastic properties}

In their investigation of the high-pressure behavior of moganite by angle-dispersive X-ray powder diffraction, Léger et al. [23] determined the bulk modulus from the pressure dependence of the molar volume, obtaining $\kappa=32.2 \mathrm{GPa}$.

Hantsch et al. [8] compared the stiffness constants obtained by their DFT calculations with the results from lattice energy minimization calculations using the program GULP [24] either with rigid ion BKS potentials [25] or with shell model SG potentials [26]. Their results for moganite are presented in Table 3 together with our results. The $\mathrm{DMol}^{3}$ code $[14,15]$ was used with basis set DNP [15] and either functional PBE [16] or PBEsol [17] to

Tab. 3: Elastic stiffness constants $c_{\mathrm{ij}}$ and bulk modulus $\kappa$ of moganite according to various authors.

\begin{tabular}{lrrrrrr}
\hline [GPa] & \multicolumn{3}{c}{ Hantsch et al. [8] } & & This paper \\
\cline { 2 - 3 } \cline { 6 - 7 } & $\begin{array}{rrrrr}\text { GULP } \\
\text { BKS }\end{array}$ & $\begin{array}{r}\text { GULP } \\
\text { SG }\end{array}$ & $\begin{array}{r}\text { D1 } \\
\text { DFT }\end{array}$ & $\begin{array}{r}\text { D2 DMol } \\
\text { PBE }\end{array}$ & $\begin{array}{r}\text { D3 DMol } \\
\text { PBEsol }\end{array}$ \\
\hline$C_{11}$ & 142.5 & 84 & 88 & 71.11 & 67.18 \\
$C_{22}$ & 111.3 & 60 & 45 & 55.81 & 56.52 \\
$C_{33}$ & 157.8 & 74 & 117 & 87.41 & 97.21 \\
$C_{44}$ & 34.9 & 14 & 15 & 31.21 & 32.90 \\
$C_{55}$ & 46.2 & 43 & 40 & 46.37 & 40.35 \\
$C_{66}$ & 40.3 & 22 & 6 & 14.56 & 10.86 \\
$C_{12}$ & 24.2 & 5 & -7 & -7.26 & -7.45 \\
$C_{13}$ & 59.1 & 3 & 27 & 7.57 & 4.46 \\
$C_{15}$ & -18.5 & 4 & -8 & -1.50 & 3.31 \\
$C_{23}$ & 24.3 & -17 & -12 & 3.58 & 6.31 \\
$C_{25}$ & 0.2 & 7 & -9 & 7.09 & 8.35 \\
$C_{35}$ & -18.9 & 3 & -5 & -7.13 & -5.46 \\
$C_{46}$ & 13.2 & 4 & 1 & -2.72 & -3.47 \\
$\kappa$ & 66.7 & 21 & 20 & 22.9 & 22.5 \\
\hline
\end{tabular}


determine the stress in strained moganite. The stiffness constants in the last two columns of Table 3 were obtained by numerical differentiation of the stresses as functions of the strains.

The results D2 and D3 obtained with the $\mathrm{DMol}^{3}$ code but different functionals agree quite well. In the discussion of their results Hantsch et al. [8] argue that their GULP BKS results for moganite are less reliable than their GULP SG and DFT results and that the bulk modulus $\kappa$ is smaller for moganite than for $\alpha$-quartz (for which $\kappa \approx 37.4 \mathrm{GPa}[27$, 28]) but higher than their GULP SG and DFT values. Our results confirm these conclusions but our bulk modulus is still considerably smaller than the value $\kappa=32.2 \mathrm{GPa}$ of Léger et al. [23].

\section{Conclusion}

The oxygen tetrahedra in our Brazil cell-twin models M1 and M2 (see Table 1) coincide in shape and size with those of quartz, i.e. their $\mathrm{Si}-\mathrm{O}$ distances and $\mathrm{O}-\mathrm{Si}-\mathrm{O}$ angles agree with those of quartz at $13 \mathrm{~K}$ and $291 \mathrm{~K}$, respectively. Although the experimentally determined lattice parameters $a, b, c$ and $\beta$ differ for E1, E2 and E3 much more than the given uncertainties, these parameters can be determined experimentally much more precisely than by means of DFT calculations, the results of which strongly depend on the functional employed. The situation is completely different for the $\mathrm{Si}-\mathrm{O}$ distances and $\mathrm{O}-\mathrm{Si}-\mathrm{O}$ angles, which determine the shape and size of the oxygen tetrahedra. The DFT calculations $\mathrm{D} 1, \mathrm{D} 2$ and $\mathrm{D} 3$ agree that the $\mathrm{Si}-\mathrm{O}$ distances decrease in the order \#5, \#1, \#6 and \#4; \#2,3 being the smallest distances. For each of the ten $\mathrm{O}-\mathrm{Si}-\mathrm{O}$ angles (\#7-16), the DFT calculations D1, D2 and D3 give similar results, which are close to those for the Brazil cell-twin models $\mathrm{M} 1$ and M2, especially in the cases, where $\mathrm{O}-\mathrm{Si}-\mathrm{O}$ does not cross a Brazil twin boundary. If $\mathrm{O}-\mathrm{Si}-\mathrm{O}$ does cross a Brazil twin boundary, one expects atomic relaxation to modify the $\mathrm{O}-\mathrm{Si}-\mathrm{O}$ angles more strongly, as confirmed by the DFT results. The experimentally determined $\mathrm{Si}-\mathrm{O}$ distances and $\mathrm{O}-\mathrm{Si}-\mathrm{O}$ angles differ wildly for E1, E2 and E3, showing that these distances and angles could not be reliably determined by experiment. We conclude that DFT calculations are much better suited to determine the shape of the oxygen tetrahedra than X-ray or neutron diffraction on powders of moganite. Taking also the $\mathrm{Si}-\mathrm{O}-\mathrm{Si}$ angles into account, we found that among the eight approaches considered in Table 1, the $\mathrm{DMol}^{3}$ code with the PBE functional gives the most convincing results for the bond angles in moganite.

\section{References}

[1] O. W. Flörke, J. B. Jones, H.-U. Schmincke, Z. Kristallogr. 1976, $143,156$.

[2] O. W. Flörke, U. Flörke, U. Giese, N. Jb. Mineral. Ab. 1984, 149, 325.

[3] G. Miehe, H. Graetsch, O. W. Flörke, H. Fuess, Z. Kristallogr. 1988, 182, 183.

[4] G. Miehe, H. Graetsch, Eur. J. Mineral. 1992, 4, 693.

[5] P. J. Heaney, J. E. Post, Amer. Mineral. 2001, 86, 1358.

[6] H. Grimmer, B. Delley, Acta Crystallogr. A 2012, 68, 359.

[7] H. Grimmer, B. Delley, Acta Crystallogr. A 2014, 70, 682.

[8] U. Hantsch, B. Winkler, C. J. Pickard, J. D. Gale, M. C. Warren, V. Milman, F. Mauri, Eur. J. Mineral. 2005, 17, 21.

[9] G. A. Lager, J. D. Jorgensen, F. J. Rotella, J. Appl. Phys. 1982, 53, 6751.

[10] W. H. Baur, Z. Kristallogr. 2009, 224, 580.

[11] A. R. Lang, Fault surfaces in alpha quartz: their analysis by $X$-ray diffraction contrast and their bearing on growth history and impurity distribution, in Crystal Growth, (Ed. H. S. Peiser) pp. 833-838. (Supplement to J. Phys. Chem. Solids). Pergamon Press, Oxford (UK), 1967.

[12] P. P. Phakey, Phys. Status Solidi 1969, 34, 105.

[13] A. C. Larson, R. B. Von Dreele, General Structure Analysis System (GSAS). Los Alamos National Laboratory Report LAUR 86-748, 1994.

[14] B. Delley, J. Chem. Phys. 1990, 92, 508.

[15] B. Delley, J. Chem. Phys. 2000, 113, 7756.

[16] J. P. Perdew, K. Burke, M. Ernzerhof, Phys. Rev. Lett. 1996, 77, 3865.

[17] J. P. Perdew, A. Ruzsinszky, G. I. Csonka, O. A. Vydrov, G. E. Scuseria, L. A. Constantin, X. Zhou, K. Burke, Phys. Rev. Lett. 2008, 100, 136406.

[18] I. Petrovic, P. J. Heaney, A. Navrotsky, Phys. Chem. Mineral. 1996, 23, 119..

[19] P. J. Heaney, D. A. McKeown, J. E. Post, Amer. Mineral. 2007, 92, 631 .

[20] G. Miehe, O. W. Flörke, H. Graetsch, Fortschr. Mineral. 1986, 64, Beih. 1, 117.

[21] M. A. Carpenter, E. K. H. Salje, A. Graeme-Barber, B. Wruck, M. T. Dove, K. S. Knight, Amer. Mineral. 1998, 83, 2.

[22] V. V. Murashov, I. M. Svishchev, Phys. Rev. B, 1998, 57, 5639.

[23] J. M. Léger, J. Haines, C. Chateau, Eur. J. Mineral. 2001, $13,351$.

[24] J. D. Gale, A. L. Rohl, Mol. Simulat. 2003, 29, 291.

[25] B. W. H. van Beest, G. J. Kramer, R. A. van Santen, Phys. Rev. Lett. 1990, 64, 1955.

[26] G. Sastre, J. D. Gale, Chem. Mater. 2003, 15, 1788.

[27] P. Heyliger, H. Ledbetter, S. Kim, J. Acoust. Soc. Am. 2003, 114, 644.

[28] H. Ogi, T. Ohmori, N. Nakamura, M. Hirao, J. Appl. Phys. 2006, 100, 053511. 